Canadian Journal of Applied Linguistics

Revue canadienne de linguistique appliquée

\title{
The Acquisition of Prepositional Meanings in L2 Spanish
}

\section{Yvonne Lam}

Volume 21, Number 1, 2018

URI: https://id.erudit.org/iderudit/1050808ar

DOI: https://doi.org/10.7202/1050808ar

See table of contents

Publisher(s)

University of New Brunswick

ISSN

1920-1818 (digital)

Explore this journal

Cite this article

Lam, Y. (2018). The Acquisition of Prepositional Meanings in L2 Spanish. Canadian Journal of Applied Linguistics / Revue canadienne de linguistique appliquée, 21(1), 1-22. https://doi.org/10.7202/1050808ar

\section{Article abstract}

This study examines how adult second language learners acquire the different meanings of the Spanish preposition a. Cognitive linguistic models predict that spatial meanings are acquired first, as they are conceptually basic and are the source from which other meanings derive via natural cognitive mechanisms such as metaphor and image-schema transformation (Tyler \& Evans, 2003). However, there has been little empirical evidence to support this hypothesis. Results from an oral story-telling task conducted with beginner $(\mathrm{N}=10)$, intermediate $(\mathrm{N}=10)$, and advanced $(\mathrm{N}=4)$ learners suggest that the acquisition of prepositional meanings is not driven solely by cognitive mechanisms, but rather that other non-conceptual factors, such as collocational patterns, cross-linguistic transfer, frequency, and saliency, also play a prominent role. These findings imply that learners approach the multiple varied meanings of a preposition by relying on several different mechanisms simultaneously.
This document is protected by copyright law. Use of the services of Érudit (including reproduction) is subject to its terms and conditions, which can be viewed online.

https://apropos.erudit.org/en/users/policy-on-use/ 


\title{
The Acquisition of Prepositional Meanings in L2 Spanish
}

\author{
Yvonne Lam \\ University of Alberta
}

\begin{abstract}
This study examines how adult second language learners acquire the different meanings of the Spanish preposition $a$. Cognitive linguistic models predict that spatial meanings are acquired first, as they are conceptually basic and are the source from which other meanings derive via natural cognitive mechanisms such as metaphor and image-schema transformation (Tyler \& Evans, 2003). However, there has been little empirical evidence to support this hypothesis. Results from an oral story-telling task conducted with beginner $(N=10)$, intermediate $(N=10)$, and advanced $(N=4)$ learners suggest that the acquisition of prepositional meanings is not driven solely by cognitive mechanisms, but rather that other non-conceptual factors, such as collocational patterns, cross-linguistic transfer, frequency, and saliency, also play a prominent role. These findings imply that learners approach the multiple varied meanings of a preposition by relying on several different mechanisms simultaneously.
\end{abstract}

\section{Résumé}

Cette étude examine la manière dont les apprenants adultes de langue seconde acquièrent les différentes acceptions de la préposition $a$ en espagnol. Les modèles de la linguistique cognitive prédisent que les acceptions spatiales sont acquises avant les autres puisqu'elles sont conceptuellement basiques et sont la source dont les autres acceptions dérivent au moyen des mécanismes cognitifs naturels tels que la métaphore et la transformation de l'imageschéma (Tyler et Evans, 2003). Cependant, il y a eu peu de preuves empiriques pour soutenir cette hypothèse. Les résultats provenant d'une tâche orale où des apprenants de niveau débutant $(N=10)$, intermédiaire $(N=10)$ et avancé $(N=4)$ racontent une histoire à partir d'images suggèrent que l'acquisition des acceptions prépositionnelles ne dépend pas seulement des mécanismes cognitifs, mais aussi d'autres facteurs non conceptuels, comme les patrons collocationnels, le transfert translinguistique, la fréquence et la saillance, qui jouent également un rôle important. Ces résultats impliquent que les apprenants abordent le problème des multiples acceptions variées d'une préposition en utilisant plusieurs mécanismes différents en même temps. 


\section{The Acquisition of Prepositional Meanings in L2 Spanish}

\section{Introduction}

Prepositions are the source of some of the most common errors among second language (L2) ${ }^{1}$ learners (e.g., Alexopoulou, 2006; Azevedo, 1980; Henning, 1978; Jiménez Catalán, 1996). A large part of their difficulty lies in the multiple and diverse meanings that can be expressed by a single prepositional form. As an example, Huerta (2009) identified no fewer than 22 senses for the Spanish preposition $a$. Moreover, as form-meaning mappings are specific to a particular language, it is often difficult to find a single translation equivalent for a given preposition, thereby rendering unhelpful the assumption of semantic equivalence between the first languages (L1s) and L2s that many learners hold (Ijaz, 1986; Taylor, 1988). For instance, depending on the context, Spanish $a$ can be translated as to, at, on, or in in English, or it may not even be expressed lexically at all. Little wonder, then, that not only are prepositional errors frequent among L2 learners, but they also persist, even into the advanced levels (e.g., Alexopoulou, 2006; Tyler, 2012).

Despite the noted difficulty of prepositions, few studies have examined how learners approach them. One hypothesis that has gained attention in recent years has been put forth by cognitive linguists, who have argued that the acquisition of prepositional meanings does not proceed haphazardly, context by context, but rather is carried out in a systematic fashion. Their claim has been based on the belief that historically, speakers must have assigned different meanings to the same form because they perceived some sort of relationship among these meanings using natural cognitive mechanisms, such as metaphor, analogy, and image-schema transformations (see Rice, 1996; Sandra \& Rice, 1995; Tyler \& Evans, 2003). Spatial notions have often been considered to be the conceptual base for these relationships, as humans interact with the world in a physical manner. For example, the core meaning of the Spanish preposition $a$ is to indicate movement towards a goal, as in voy a la tienda [I go to the store] (see Huerta, 2009). By focusing on the end of the path of motion (an image-schema transformation), $a$ can also be used to express location, such as in se sentó a la mesa [he sat down at the table]. The concept of location in space can then be extended metaphorically to location in time, thus accounting for the use of $a$ to express the moment at which an event occurs, as in llegó a las siete [he arrived at seven o'clock]. In this way, cognitive linguists have argued that the use of $a$ to express direction, location, and time is not arbitrary, but rather is motivated by basic cognitive processes.

As these processes are part of the conceptual system, cognitive linguists reason that they should be at play during language acquisition as well. Consequently, the acquisition of prepositions should start with the concrete, semantically transparent, spatial uses from which learners can subsequently derive other, more abstract uses using natural cognitive mechanisms. Unfortunately, there has been little empirical evidence to date to support this hypothesis. The few studies that have directly examined the development of prepositional meanings, whether in L1 or in L2, have failed to show conclusively that learners are sensitive to conceptual basicness (e.g., Hallan, 2001; Rice, 1999, 2003 for L1; see the following section for L2 studies). Similarly, studies that examined the effect of teaching L2 learners how different meanings relate to each other have also yielded mixed results: while some found greater accuracy in production overall (e.g., Boers \& Demecheleer, 1998; Cho, 2010; Tyler, 2012; Tyler, Mueller, \& Ho, 2011), others only noted improvement in specific aspects of performance (e.g., Lam, 2009; Matula, 2007; Morimoto \& Loewen, 2007). Thus,

The Canadian Journal of Applied Linguistics: 21, 1 (2018): 1-22 
the question of how learners acquire the different meanings of a preposition remains largely unanswered.

This study contributes more data on the development of prepositional meanings in L2 learners, specifically for the Spanish preposition $a$, by testing the predictions made by cognitive linguists. Using a story-telling task administered to a cross-sectional sample of university Spanish learners, the following research questions were examined:

1. Which uses of the Spanish preposition $a$ are produced more accurately by L2 learners?

According to cognitive linguists, more conceptually basic uses are acquired before less semantically transparent ones. Consequently, learners should show greater accuracy with spatial uses, followed by the relatively transparent temporal extensions, then the lexical uses, and finally, the least semantically transparent grammatical uses (see Rice, 1999, 2003).

2. What factors influence how learners use the preposition $a$ ?

Cognitive linguists have attributed a primary role to conceptual basicness and other cognitive mechanisms such as metaphor, analogy, and image-schema transformations. However, previous studies have also identified collocational strength, frequency, saliency, and similarity to the L1 as influential factors (see the following section and the discussion for references). These additional factors will be taken into account in the data analysis.

\section{Literature Review}

Only a handful of empirical studies has examined the acquisition of the multiple meanings of the same preposition in an L2. For Spanish, the studies have concentrated on the prepositions por and para, which are often singled out because they can both be translated as for in English and are thus perceived to be a particular source of difficulty for learners. The first study was carried out by Guntermann (1992) based on interviews with nine English-speaking Peace Corps volunteers in a Latin American country. For para, the earliest uses were to express purpose and beneficiary, which accounted for over $80 \%$ of accurate attempts; despite being conceptually basic, spatial expressions only made up 5\% of accurate uses. Likewise, the earliest use of por was temporal, which, together with fixed expressions, accounted for 55\% of accurate uses, while spatial uses only constituted $19 \%$. Lafford and Ryan (1995) interviewed nine English-speaking learners in a study-abroad program in Spain and found comparable results: The purpose and beneficiary uses of para accounted for $64 \%$ of accurate uses, while spatial goal only made up $1 \%$. For por, temporal uses and fixed expressions made up $76 \%$ of the accurate attempts, whereas spatial uses only constituted $8 \%$. Based on these data, Lafford and Ryan proposed an acquisition order in which the spatial uses of por were the last of the attested uses to appear, and the spatial uses of para were fourth out of seven observed uses. Pinto and Rex (2006) administered a discourse completion task to a cross-section of 80 English-speaking university Spanish students and found that, similar to previous studies, the most frequent uses of para were to express purpose and beneficiary (94.6\% of accurate uses), while the most frequent uses of por were duration, motive, and fixed expressions (94\%). It is worth noting that their 
instrument failed to elicit a single spatial use from the L2 learners, even though a control group of 44 native Spanish speakers did produce spatial expressions when given the same task.

A few other studies have looked at how learners acquire prepositional meanings in L2 English. González-Alvarez and Doval-Suárez (2008) examined the acquisition of at by native Spanish speakers at an advanced level of L2 English using data from the International Corpus of Learner English. They found that at was used most frequently to express time (42.9\%), followed by space $(29.5 \%)$, with the difference being statistically significant. The authors attributed the prominence of temporal uses to the frequent use of three expressions (at the end, at the same time, at the beginning) that were likely learned as fixed units. Navarro i Ferrando and Tricker (2000/2001) studied the use of at, on, and in by 74 native speakers of Spanish or Catalan studying English at the first- and third-year university levels. Using a sentence generation task in which learners had to produce 10 distinct sentences in 10 minutes for each preposition, they found that for at, there was a predominance of temporal and idiomatic uses over spatial ones, whereas for on and in, spatial uses were more numerous, although there were still many temporal and idiomatic uses. The authors also administered a ratings similarity task in which 17 participants compared a given sentence to a model one based on the primary spatial meaning. They found that the L2 learners did perceive an intuitive semantic difference between primary and non-primary meanings, although the considerable variation among students within the same group suggested that they had learned common collocations rather than the meaning itself. Cho (2010) examined the acquisition of the spatial topological and spatial functional uses of in, on, and at in intermediate-level L2 English by native Japanese speakers. She found that learners performed more accurately on a fill-in-the-blank task with concrete spatial uses than with more abstract spatial extensions. However, the range of uses elicited was too limited for deducing a developmental pattern, and the task was highly controlled, which did not allow for examination of factors such as collocational patterns.

While these studies do not constitute sufficient evidence to determine whether cognitive mechanisms motivate the acquisition of prepositional meanings, the majorityCho (2010) being the exception-suggest the contrary. Despite the conceptual basicness of spatial meanings, these uses are not necessarily acquired first; rather, developmental patterns appear to be susceptible to other factors. One such factor that showed up repeatedly was collocation; learners seemed to be attuned to which words appear together (see also Durrant \& Schmitt, 2010), leading them to treat fixed expressions and multiword constructions as a single "chunk" due to the frequency of co-occurrence of its parts. A similar strategy has also been observed in the L1 acquisition of English (Rice, 2003). In this study, collocational patterns also appear to play a major role in how learners acquire prepositional meanings.

It should be noted as well that the findings in these studies, except Cho (2010), are based on how frequently a given meaning was used as a proportion of all accurate tokens. Such frequencies are not necessarily indicative of acquisition because they can be skewed in favour of more communicatively useful meanings. The fact that a meaning is not used may not be due to its lack of acquisition (although that remains a possibility), but rather that there were few opportunities to use it. The same limitation applies to the sentence generation task used by Navarro i Ferrando and Tricker (2000/2001); when asked to produce random sentences, learners are more likely to use the meanings that they are most comfortable with, but this preference does not necessarily imply a lack of knowledge of the 
other meanings. Pinto and Rex's (2006) study is the most suggestive of a failure to acquire certain uses because native speakers did produce the full range of meanings, although the open-endedness of the task makes it difficult to know if learners lacked knowledge of these uses or if they simply interpreted the scenario differently. A more informative analysis would be to compare each meaning with itself rather than as a proportion of all uses, as done below, thereby controlling for communicative usefulness.

\section{Method}

\section{Participants}

Given the difficulties of conducting a longitudinal study with the same group of learners, this study used instead a cross-sectional sample of learners enrolled in Spanish language and content courses at a Canadian university in order to approximate development over time. The study was conducted outside of class time, and participants received no compensation, which may have contributed to the small sample size of 24 volunteer students. Six students were male, while 18 were female. The majority of the participants ( $n$ $=18$ ) were between the ages of 18 and 25 years, three were between 25 and 35 years old, and three were over 35 years of age. The participants were divided into three groups based on the course level in which they were registered at the time as well as the results of a lexical decision test used to measure overall language proficiency (see Lam, 2010). In Level 1, there were 10 students, nine of whom were registered in Beginners' Spanish, while the tenth was registered in Intermediate Spanish but had a proficiency score in the Level 1 range (2.5 standard deviations below the mean score for Level 2). Level 2 also had 10 students; nine were registered in Intermediate Spanish, with one in Beginners' Spanish but scoring at the intermediate level on the proficiency test (2.2 standard deviations above the mean score for Level 1). In Level 3, there were four students, all of whom had completed the high-intermediate language course and were enrolled in advanced courses on Spanish culture, linguistics, and translation.

Nineteen of the 24 students identified themselves as native English speakers.

Twelve of them spoke at least one other language in addition to English and Spanish: 10 spoke some French (seven did so rarely, while three spoke it weekly); two knew some German; and one student each claimed some use of Hungarian, Italian, Welsh, and Ukrainian. The five students who were not native English speakers listed Polish, Russian, Arabic, German, and Japanese as their L1s. These five students were retained in the sample, as form-meaning mappings are language-specific, so it is unlikely that a particular L1 (especially a non-Romance language) would confer a special advantage. Moreover, it is not improbable that their Spanish, just like the Spanish of their native English speaker classmates, was influenced by English, given that they used English on a daily basis (see Falk \& Bardel, 2010). In fact, when the performance of these students was examined individually, it did not differ noticeably from the rest of their group, and an analysis that excluded these students led to the same overall results as one that included them. As a baseline for comparison, a group of five native Spanish speakers from Spain and different

parts of Latin America who were students or instructors at the university were also asked to complete the task. ${ }^{2}$

The way in which the students learned the different uses of $a$ was not considered, as this study does not examine the role of instruction. However, given that the classroom was 
the primary context of exposure to Spanish for the participants, it is worth noting that the language program at this university followed a popular textbook series that had a strong focus on grammar and vocabulary. To the extent that $a$ was taught explicitly, the uses were presented individually as discrete items, either under the grammar section for the grammatical uses, or as vocabulary items. At no point were the uses of $a$ presented in a single unit, as advocated by cognitive linguists, and none of the instructors would have had sufficient training in linguistics to create such a lesson on their own. As for the Spanish input students received outside the classroom, 16 participants reported having travelled to a Spanish-speaking country for periods ranging from a minimum of 2 weeks to a maximum of 29 months; eight participants spoke Spanish to friends on a regular basis; and 16 participants had weekly exposure to Spanish-language media.

\section{Instruments}

An oral story-telling task was chosen as the main instrument because it captured spontaneous speech while at the same time allowing for the elicitation of $a$ by manipulating what the pictures in the story depicted. Four general uses of $a$ were targeted: spatial, temporal, lexical, and grammatical (see the following section for examples). Each story, designed specifically for this study, consisted of 15 black-and-white pictures on a single page (see Appendices). The pictures represented, as much as possible, common situations that students should be able to describe, however briefly, in Spanish. As the data from the native-speaker group show (Table 1), there were plentiful opportunities to produce $a$ in a variety of ways. While it is not possible to list every use of $a$ that the stories may elicit, the following summaries will provide the reader who is knowledgeable in Spanish with some indication of where the participants may have used it.

The first story (Appendix A) involves a young man waiting to go to the movies at three o'clock. He stops at the café next door and orders a slice of cake from the waiter. While he waits, he writes a letter to his girlfriend. When the cake arrives, it tastes like moldy cheese, so he throws it on the floor and orders another slice. In the meantime, he watches some men playing cards and some people getting on a bus. Finally, tired of waiting, he loudly demands his cake, at which point four waiters come running, each carrying a slice.

The second story (Appendix B) shows a family going on vacation to the mountains. As they arrive at the lake, it begins to rain heavily. Stuck in their camper, they watch television and talk to each other. The boy wishes he were swimming in the lake, while the girl thinks about horseback riding. The father wonders when he will get to play golf with the new club his wife gave him, while the mother would rather be sun-bathing. As it continues to rain, the boy thinks about the homework he has to do, and his mother remembers that she is meeting a friend for coffee. Finally, the family decides to leave. As they drive out of the park, it stops raining, and the sun comes out.

\section{Procedure}

Participants were given written instructions in English to ensure understanding of what was expected. They were not told that the focus was on the preposition $a$ but were simply informed that samples of stories in L2 Spanish were being collected and that it did not matter how accurate their Spanish was. They were shown the stories in their entirety 
one at a time, with the order counterbalanced across participants. They were told that they had 1 minute to look over the pictures (assuming 4 seconds per picture) and request, in English, any vocabulary items or clarifications of the images. They were then asked to describe each picture in sequence, paying attention to the details and making the stories as elaborate as possible. There was no time limit to the task, and the stories were audio recorded.

The research assistant was instructed to provide only minimal help: If asked for clarification of what was depicted in an image, he answered in English so as not to provide unintentional input of the preposition $a$, and if a vocabulary item in Spanish was requested, he replied in as few words as possible, giving only the bare form. While he used physical cues to indicate that he was listening, he did not ask questions to prompt the students to speak. The recorded stories were transcribed by the research assistant, then checked by a second research assistant, and again by the researcher, as the preposition $a$ is not acoustically salient and can sometimes resemble the expression of hesitation. Where there was doubt, the majority opinion prevailed.

\section{Data Analysis}

Uses of $\boldsymbol{a}$. The tokens of $a$ produced by the learners were placed into four categories: spatial, temporal, lexical, and grammatical. Note that these categories do not represent the full range of meanings of $a$ (see Huerta, 2009, for a more detailed classification). However, given the limited number of tokens in the corpus - 351 in total-a fine-grained categorization would result in few or no tokens for many of the meanings, thereby obscuring general patterns. A more detailed description of each category is given below, along with examples from actual utterances produced by participants.

Spatial uses. The core meaning of $a$ (from Latin ad [towards]) is to express movement towards a goal (Huerta, 2009). $A$ can be used either in a directional sense with verbs of movement, as in example (1), or extended to a locative sense, as in (2), via an image-schema transformation that focuses on the endpoint of movement (Huerta, 2009).

(1) Va al café. [He goes to the café.]

(2) Se sienta a una mesa. [He sits down at a table.]

Expressions such as montar a caballo [to go horseback riding] and sentarse al sol [to sit in the sun] were treated as lexical rather than spatial; while $a$ does express a spatial notion, these expressions behave as fixed units, as no other preposition can be used. In contrast, paradigmatic variation is possible in examples (1) and (2) above (e.g., va detrás del café [he goes behind the café], se sienta sobre la mesa [he sits down on the table]).

Temporal uses. Temporal notions are commonly derived from spatial expressions (Haspelmath, 1997), and indeed, $a$ can designate the moment in time at which an event occurs via a metaphorical extension of the locative use of $a$, as shown in example (3).

(3) La pelicula es a las tres. [The film is at three o'clock.] 
Lexical uses. This category encompasses the constructions where $a$ is a fixed element in an expression, and its meaning has largely been bleached out by the idiomatic nature of the expression, although its semantic origin can sometimes be traced to spatial meanings. For instance, the expression of futurity ir a VERB, illustrated in example (4), likely derives from the directional meaning of $a$, in that movement towards a goal implies intention:

(4) Va a pedir un pastel. [He's going to order a piece of cake.]

Similarly, in (5), llover [to rain] can be considered the "goal" of empezar [to begin] (Huerta, 2009, pp. 97-98):

(5) Empieza a llover. [It begins to rain.]

In example (6), Huerta (2009) considered the expression of resemblance as being "located" relative to a point of comparison (pp. 95-96):

(6) Sabe a queso viejo. [It tastes like old cheese.]

It is unclear to what extent these semantic relationships are transparent to learners; in fact, for many of these expressions $a$ is listed as a collocate. For this reason, they are grouped under the lexical category, with the other categories reserved for more productive uses of $a$.

Grammatical uses. This category refers to the use of $a$ to signal the object of a verb, whether it be the indirect object of a ditransitive verb, as in example (7); the object of a bivalent intransitive verb (a verb that takes a subject and an indirect object but no direct object), as in (8); or the direct object of a transitive verb when the object is considered animate (the so-called "personal $a$ " use), as in (9):

(7) Le escribe la carta a su novia. [He writes the letter to his girlfriend.]

(8) A él no le gusta comer. [He doesn't like eating (lit. eating doesn't please him).]

(9) Vio a su novia. [He saw his girlfriend.]

Again, although these uses of $a$ can be traced to a spatial origin - the action is "directed towards" someone or something (Huerta, 2009, pp. 99-100) - its semantic value has largely been bleached out by grammaticalization.

Coding procedure. Each token of $a$ was placed in one of the four categories above and coded as correct or incorrect. Omissions of $a$ in obligatory contexts were coded as incorrect. The absence of $a$ in non-obligatory contexts was not counted, as there is variation even among native speakers as to which preposition is used in certain expressions (e.g., sentarse a/en la mesa [to sit down at the table]) or whether $a$ is present at all (e.g., jugar cartas or jugar a cartas [to play cards]). Immediate repetitions (e.g., a la a su casa [to the to his house]) were counted as one token. The omission of $a$ preceding or following the sound /a/ (e.g., va (a) comer [he's going to eat]) was not considered an error because native speakers often reduce two consecutive /a/ to a single one, so it was possible that the learner was merely imitating native-speaker phonological patterns. Where there was doubt about a 
specific use of $a$, the $20^{\text {th }}$ century portion of the Corpus del Español (Davies, 2002) was consulted in order to see if such a use is indeed attested in native speakers.

In order to determine interrater reliability, the transcripts for each level were organized in ascending numerical order by participant number. Using a random number generator, the researcher selected the corresponding transcripts until a minimum of $20 \%$ of the total tokens of $a$ produced at that level was represented. The resulting subsample contained two transcripts from Level 1, and one transcript each from Level 2, Level 3, and Native Speakers. A graduate student with experience in teaching Spanish as a second language was asked to code the data following the procedure described above. Of the 133 tokens identified by one or both the researcher and the interrater, there was agreement on 127 of them, yielding an interrater reliability rate of $95 \%$.

\section{Results}

The four categories of uses are first examined together in order to determine which uses were produced more accurately. Then, each category is considered individually to obtain a greater understanding of what factors may have influenced learners' performance.

\section{Total Uses}

Table 1 indicates the number of contexts where $a$ was used or should have been used. It also shows how often each category of use occurred as a percentage of the total number of tokens. As a baseline for comparison, the results from the native-speaker sample are also included. The average number of uses per L2 level was generally comparable; Level 1 had the lowest average but also noticeably shorter narratives due to the lower proficiency level. The native speakers had the highest average number of tokens, as they produced much lengthier narratives. The participants were clearly aware of the different ways in which $a$ can be used: All four categories were attempted at all levels. The temporal uses appeared with relatively lower frequency, but this was likely due to the limited opportunities to indicate when an event took place rather than to a lack of acquisition, as its use was low even among the native speakers.

Table 1

Total Uses of A by Category and Level

\begin{tabular}{lllllll}
\hline Level & Total & $\begin{array}{l}\text { Average } \\
\text { Per } \\
\text { Speaker }\end{array}$ & $\begin{array}{l}\text { Spatial } \\
(\% \text { of } \\
\text { Total })\end{array}$ & $\begin{array}{l}\text { Temporal } \\
(\%)\end{array}$ & $\begin{array}{l}\text { Lexical } \\
(\%)\end{array}$ & $\begin{array}{l}\text { Grammatical } \\
(\%)\end{array}$ \\
\hline Level 1 $(N=10)$ & 122 & 12.2 & 34 & 5 & 30 & 31 \\
Level 2 $(N=10)$ & 167 & 16.7 & 35 & 9 & 37 & 20 \\
Level 3 $(N=4)$ & 62 & 15.5 & 27 & 11 & 35 & 26 \\
All Levels $(N=24)$ & 351 & 14.6 & 33 & 8 & 34 & 25 \\
Native Speakers $(N=5)$ & 105 & 21.0 & 25 & 10 & 48 & 17 \\
\hline
\end{tabular}

\section{Accuracy of Use}

Table 2 shows how accurately $a$ was used by each level, overall and for each category. As expected, overall accuracy increased with proficiency. Accuracy also 
increased with proficiency for the spatial, lexical, and grammatical categories. The exception is the temporal category, which exhibited the U-shaped behaviour found in numerous L2 acquisition studies, in which beginner learners produce accurate target-like utterances, then appear to regress before returning to more normative behaviour. The possible cause for this pattern will be discussed in a later section.

Table 2

Accuracy of Use of A by Category and Level

\begin{tabular}{|c|c|c|c|c|c|c|c|c|c|c|}
\hline Level & \multicolumn{2}{|c|}{ Total } & \multicolumn{2}{|c|}{ Spatial } & \multicolumn{2}{|c|}{ Temporal } & \multicolumn{2}{|c|}{ Lexical } & \multicolumn{2}{|c|}{ Grammatical } \\
\hline & $\%$ & \# & $\%$ & \# & $\%$ & $\#$ & $\%$ & \# & $\%$ & \# \\
\hline Level 1 & 52 & $63 / 122$ & 74 & $31 / 42$ & 100 & $6 / 6$ & 36 & $13 / 36$ & 32 & $12 / 38$ \\
\hline Level 2 & 63 & $105 / 167$ & 79 & $46 / 58$ & 80 & $12 / 15$ & 52 & $32 / 61$ & 42 & $14 / 33$ \\
\hline Level 3 & 81 & $50 / 62$ & 94 & $16 / 17$ & 100 & $7 / 7$ & 73 & $16 / 22$ & 69 & $11 / 16$ \\
\hline All Levels & 62 & $218 / 351$ & 79 & $93 / 117$ & 89 & $25 / 28$ & 51 & $61 / 119$ & 43 & $37 / 87$ \\
\hline
\end{tabular}

A Pearson's chi-squared test was conducted using the statistics program $R$ in order to examine the relationship between proficiency level and accuracy of use for each category. For Level 1, a significant difference was found among the categories, $\chi^{2}(3, N=$ $122)=29.00 ; p<.001$. The Pearson residuals (Table 3 ) showed that both spatial and temporal uses were significantly more accurate than predicted by the null hypothesis (a proportional distribution of accuracy), while lexical and grammatical uses were significantly less accurate. For Level 2 , there was also a significant difference among the four categories, $\chi^{2}(3, N=167)=17.21 ; p<.001$; spatial uses were significantly more accurate, grammatical uses were significantly less accurate, and temporal and lexical uses were neither more nor less accurate than predicted. As for Level 3, there were too few instances of incorrect responses for the chi-squared test to work properly. Consequently, Level 3 was combined with Level 2, and a significant result was returned, $\chi^{2}(3, N=229)=$ $20.95 ; p<.001$. Spatial and temporal uses were significantly more accurate than the null hypothesis, while lexical and grammatical uses were significantly less accurate.

Table 3

Pearson Residuals for Relationship Between Proficiency Level and Accuracy of Use

\begin{tabular}{lllll}
\hline Level & Spatial & Temporal & Lexical & Grammatical \\
\hline Level 1 & + & + & - & - \\
Level 2 & + & 0 & 0 & - \\
Levels 2 \& $3^{a}$ & + & + & - & - \\
\hline
\end{tabular}

Note. $0=$ distribution predicted by null hypothesis (proportional distribution of accuracy); + = significantly more accurate than predicted by null hypothesis; - = significantly less accurate than predicted by null hypothesis. Significant at $p<.05$.

${ }^{a}$ Level 3 could not be analyzed separately due to an insufficient number of responses in some cells. 
Pairwise comparisons were also conducted to check for significant differences among the uses (Table 4). There was no significant difference between spatial and temporal uses at any level, nor between lexical and grammatical uses. In contrast, spatial and lexical uses, and spatial and grammatical uses, were significantly different at all levels. Temporal and lexical uses were significantly different only at Level 1, while temporal and grammatical uses were significantly different at Level 1, and at Levels 2 and 3 combined.

Table 4

Pairwise Comparisons for Accuracy of Use

\begin{tabular}{llll}
\hline Uses & Level 1 & Level 2 & Levels 2 \& 3 \\
\hline Spatial-Temporal & & $*$ & $*$ \\
Spatial-Lexical & $*$ & $*$ & $*$ \\
Spatial-Grammatical & $*$ & & $*$ \\
Temporal-Lexical & $*$ & & \\
Temporal-Grammatical & $*$ & & \\
Lexical-Grammatical & & &
\end{tabular}

Note. ${ }^{*} p<.008$ using Bonferroni correction for multiple comparisons.

Additionally, the results were examined for differences among the three levels for a given use (Table 5). For spatial and temporal uses, the Pearson chi-squared test found no significant differences among the levels, $\chi^{2}(2, N=117)=3.06 ; p=.21$ and $\chi^{2}(2, N=28)$ $=2.91 ; p=.23$ respectively. For lexical uses, a significant difference was found in favour of the higher levels, $\chi^{2}(2, N=119)=13.05 ; p<.001$, with the residuals showing accuracy increasing as proficiency increased; the same was found for grammatical uses, though less strongly, $\chi^{2}(2, N=87)=6.37 ; p=.04$. Pairwise comparisons confirmed the findings, with the only significant difference (Bonferroni-adjusted $p<.02$ ) being between Level 1 and Level 3 for both the lexical and grammatical categories.

Table 5

Pearson Residuals for Differences Among Levels

\begin{tabular}{llll}
\hline Use & Level 1 & Level 2 & Level 3 \\
\hline Spatial & $\mathrm{n} / \mathrm{s}$ & $\mathrm{n} / \mathrm{s}$ & $\mathrm{n} / \mathrm{s}$ \\
Temporal & $\mathrm{n} / \mathrm{s}$ & $\mathrm{n} / \mathrm{s}$ & $\mathrm{n} / \mathrm{s}$ \\
Lexical & - & 0 & + \\
Grammatical & 0 & 0 & + \\
\hline
\end{tabular}

Note. $\mathrm{n} / \mathrm{s}=$ not significant; $0=$ distribution predicted by null hypothesis (proportional distribution of accuracy); $+=$ significantly more accurate than predicted by null hypothesis; - = significantly less accurate than predicted by null hypothesis. Significant at $p<.05$.

Taken together, the results indicate no significant difference between the accuracy of spatial and temporal uses at any level. Both categories showed a high level of accuracy from Level 1 on. In contrast, lexical and grammatical uses showed a low level of overall accuracy, with no significant difference between the two categories at any level, although accuracy did increase with proficiency. Lexical uses appeared to be marginally more accurate than grammatical ones in that the significant difference between temporal and lexical uses only held at Level 1, but not in subsequent levels, while the difference between 
temporal and grammatical uses was significant at Level 1, and at Levels 2 and 3 combined. Moreover, the effect of proficiency level on accuracy was slightly stronger for lexical uses than for grammatical ones.

\section{Spatial Uses}

If the acquisition of prepositional meanings relies primarily on conceptual basicness, then it is expected that the directional use of $a$ develops before the locative use, as the latter is an extension of the former. At first glance, that did indeed seem to be the case (Table 6). However, a Pearson's chi-squared test revealed that the difference in accuracy was barely statistically significant for Level $1, \chi^{2}(1, N=42)=3.88 ; p=.049$; and not at all significant at Levels 2 and $3, \chi^{2}(1, N=58)=0.35 ; p=.56$ and $\chi^{2}(1, N=17)=$ $1.20 ; p=.27$ respectively.

Table 6

Accuracy of Directional and Locative Uses of A

\begin{tabular}{lllll}
\hline Level & $\begin{array}{l}\text { Directional } \\
\text { Total }\end{array}$ & \% Correct & $\begin{array}{l}\text { Locative } \\
\text { Total }\end{array}$ & \% Correct \\
\hline Level 1 & 29 & 83 & 13 & 54 \\
Level 2 & 38 & 82 & 20 & 75 \\
Level 3 & 8 & 88 & 9 & 100 \\
All Levels & 75 & 83 & 42 & 74 \\
\hline
\end{tabular}

Even if the evidence in favour of directional $a$ were more robust, it is not clear that conceptual basicness would necessarily be the influential factor, as an examination of the data reveals other possible explanations. First, directional $a$ seems to be more widely used than locative $a$. In a random sample of 200 tokens of $a$ from the $20^{\text {th }}$ century portion of the Corpus del Español (Davies, 2002), although there were few occurrences of spatial uses overall, directional $a$ was twice as frequent as locative $a$, appearing nine times as opposed to four. While by no means definitive, this observation suggests that directional $a$ may have been acquired first simply because it occurred more frequently in the input. In fact, the native-speaker group in this study only produced one token of locative $a$ out of 26 uses of spatial $a$.

An alternative explanation can be found by examining how $a$ maps to English, as previous studies have found that learners were influenced by the semantics of their L1 when they used prepositions in an L2 (e.g., Ijaz, 1986; Jarvis \& Odlin, 2000). Directional $a$ has a one-to-one match with English $t o$, while locative $a$ corresponds to several English prepositions: at, on, and in. An analysis of errors for Level 1 shows that only $20 \%(1 / 5)$ of the errors with directional $a$ involved confusion with other prepositions: The participant in question incorrectly used *tira la torta sobre el suelo instead of tira la torta al suelo [he throws the cake on the ground]. Note that the use of sobre [on] reflects the English convention of expressing the endpoint of the motion, whereas Spanish expresses the direction of movement, thus supporting the case for cross-linguistic transfer. In contrast, $83 \%(5 / 6)$ of the errors with locative $a$ showed confusion with other prepositions (e.g., *tiene muchas tareas a la casa instead of en casa [he has a lot of homework to do at home], * el campo a las montañas instead of en las montañas [the camp in the mountains]), as there is a less clear correspondence between locative $a$ and English prepositions. Thus, while 
learners at all levels showed some paradigmatic confusion, the more direct relationship of directional $a$ to English to would have made its semantic function more transparent to beginner learners.

Collocational patterns may also account for why Level 1 learners performed better with directional $a$. For instance, 66\% (19/29) of its uses at this level were with the verb ir [to go], whereas there was no dominant pattern in the use of locative $a$ - the most frequent collocation was with the verb sentarse [to sit down], and it only accounted for $38 \%(5 / 13)$ of the uses. Therefore, the greater accuracy of directional $a$ at Level 1 may simply be due to learners repeating ir $a$ as a set phrase. In fact, two of the Level 1 learners produced the incorrect lexical expression *ir a las vacaciones rather than the correct ir de vacaciones [to go on vacation], which supports the collocational strength of $i r a$.

In sum, although conceptual basicness may account for the greater accuracy of directional $a$ over locative $a$, it is far from clear that it plays a primary role as cognitive linguists predict, as learners may have been simultaneously influenced by non-conceptual factors such as input frequency, cross-linguistic transfer, and collocational patterns.

\section{Temporal Uses}

As described earlier, the temporal uses of $a$ were consistently accurate across all three levels, with no errors produced at Levels 1 and 3, and no significant differences in accuracy among the levels. Only three errors occurred at Level 2, and two of them involved the repetition of the same erroneous expression by the same learner. Such a developmental pattern, known as a U-shaped curve, suggests that lexical learning, rather than conceptual restructuring, is at play (Lafford \& Ryan, 1995). In this case, collocational patterns appear to figure strongly in how the temporal function of $a$ develops. When the tokens that indicate time of day (a las $X$ [at X o'clock]) were separated from other more productive uses of $a$ (e.g., al día siguiente [the following day], al llegar [on arriving]), it becomes clear that the use of $a$ to express hour was clearly learned as a unit (Table 7). There were no errors with this construction, and it was the sole use of temporal $a$ at Level 1. Although this use of $a$ is not particularly useful nor frequent - it only occurred once in the 200-token sample from the Corpus del Español, while the other uses occurred six times, and similarly, the nativespeaker group used non-hour expressions slightly more than hour expressions (six uses versus five uses) - it is a simple construction with no alternate form, and it has a direct equivalent in English. Learners did not attempt to extend the expression of time until Level 2 , resulting in errors due to the confusion between $a$ and other prepositions (*en el fin de domingo instead of al final de domingo [at the end of Sunday], plus two instances of * a las tres a la tarde instead of de la tarde [at three in the afternoon]). Once again, the early stages of acquisition seem to be influenced by non-conceptual factors, namely collocations and cross-linguistic equivalence. 
Table 7

Accuracy of the Different Temporal Uses of A

\begin{tabular}{lllll}
\hline Level & $\begin{array}{l}\text { Hour Expressions } \\
\text { Total }\end{array}$ & \% Correct & $\begin{array}{l}\text { Other } \\
\text { Total }\end{array}$ & $\%$ Correct \\
\hline Level 1 & 6 & 100 & 0 & - \\
Level 2 & 6 & 100 & 9 & 67 \\
Level 3 & 5 & 100 & 2 & 100 \\
All Levels & 17 & 100 & 11 & 73 \\
\hline
\end{tabular}

\section{Lexical Uses}

Although the data remain silent as to whether learners were relating the lexical uses of $a$ to more conceptually basic ones, the nature of some of the errors point to influence from English as a factor. Table 8 lists some of the incorrect expressions produced by the learners that could be calques of the English equivalents. Only errors that were produced by more than one learner are listed, in order to rule out idiosyncrasy. While the data are insufficient to show conclusively that cross-linguistic influence is at play (see Jarvis, 2000), the potential for transfer from English cannot be completely disregarded.

Table 8

Incorrect Lexical Uses of A That May Be Due to Transfer from English

\begin{tabular}{|c|c|c|c|c|}
\hline \multirow[t]{2}{*}{ Incorrect Expression $^{\mathrm{a}}$} & \multirow[t]{2}{*}{ English Equivalent } & \multicolumn{3}{|c|}{ \# of Learners Producing Error } \\
\hline & & Level 1 & Level 2 & Level 3 \\
\hline $\begin{array}{l}\text { *jugar las cartas/el golf } \\
\text { (jugar a las cartas/al golf) }\end{array}$ & to play cards/golf & 3 & 5 & \\
\hline $\begin{array}{l}\text { *ver/mirar a algo } \\
(\text { ver/mirar algo) }\end{array}$ & to look at something & 3 & 2 & \\
\hline $\begin{array}{l}\text { *empezar/comenzar }+ \text { verb } \\
(\text { empezar/comenzar } a+\text { verb })\end{array}$ & to begin + verb & 2 & 1 & \\
\hline $\begin{array}{l}\text { * sentarse en el sol } \\
\text { (sentarse al sol) }\end{array}$ & to sit in the sun & 1 & 1 & \\
\hline $\begin{array}{l}\text { *tiene el sabor de queso } \\
\text { (tiene sabor a queso) }\end{array}$ & it has the taste of cheese & 1 & 1 & 2 \\
\hline $\begin{array}{l}\text { *en caballo } \\
(\text { a caballo })\end{array}$ & on horseback & & 1 & 1 \\
\hline
\end{tabular}

${ }^{\mathrm{a}}$ Correct expression given in parentheses.

${ }^{b}$ While there is variation between the inclusion and the exclusion of $a$ in the expression jugar (a) cartas, with the definite article the use of $a$ is required. 
Collocational patterns may also have played a role, as in the earlier example of *ir a las vacaciones [to go on vacation], due to the strong collocation between ir and $a$.

Similarly, five learners (two at Level 1 and three at Level 2) used *pensar a su novia rather than pensar en [to think of his girlfriend], as $a$ is often used to signal an animate direct object. Moreover, frequency effects cannot be ruled out. Higher frequency expressions such as mirar [to look at] (approximately 10,000 tokens in the Corpus del Español) and empezar/comenzar a [to begin to] (8,000 tokens) were only problematic at the lower levels. In contrast, the expressions that continued to be difficult at Level 3 were all of lower frequency, such as sabor $a$ [the taste of] (60 tokens) and a caballo [on horseback] (200 tokens).

In sum, while it is certainly possible that the errors with the lexical uses of $a$ reflected difficulties in semantic extension, the potential influence of transfer as well as collocational patterns and frequency of occurrence in the input cannot be discounted. The acquisition of the lexical uses of $a$ may simply involve the rote learning of individual expressions one by one rather than a more systematic application of cognitive mechanisms.

\section{Grammatical Uses}

Table 9 divides the grammatical uses of $a$ according to the three syntactic contexts in which it occurs. Conceptual factors are unlikely to play much of a role as the grammatical use of $a$ carries little semantic value but rather is merely a morphosyntactic marker for the object of the verb; Huerta herself (2009) considered grammatical uses peripheral to her description of the semantics of $a$. Indeed, the developmental pattern can be explained based simply on the degree of similarity with English. The use of $a$ to mark the indirect object of ditransitive verbs corresponds to the English dative construction and therefore, not surprisingly, was by far the most accurate at all levels. Five of the nine errors were due to the application of the so-called English "dative shift," which is not permitted in Spanish (e.g., *da el hombre queso [he gives the man cheese]). As for bivalent intransitive verbs, most of them correspond to transitive verbs in English, so the accuracy rate was predictably low at all levels, as learners erroneously used the Spanish verb in a transitive construction (e.g., *el hombre no gusta la torta instead of al hombre no le gusta la torta [the man doesn't like the cake (lit. the cake does not please the man)]). Similarly, for transitive verbs, English does not syntactically mark animate direct objects, so it is little wonder that learners had great difficulty with this construction at all levels, despite it being the most frequent context for the grammatical use of $a$. In the 200-token sample from the Corpus del Español, the use of $a$ with transitive verbs occurs 19 times, compared to 10 tokens for the ditransitive and six tokens for the bivalent intransitive; similarly, in the native-speaker group, seven of the 18 tokens were with transitive verbs, as opposed to five for the ditransitive and six for the bivalent intransitive. Nonetheless, the use of $a$ in a transitive construction has a low functional load, as the direct object can be identified using other factors such as word order, verb agreement, and contextual cues, which would make it of low salience to learners. The results of pairwise comparisons using Pearson's chisquared tests - all three levels were summed as there were insufficient cases in many cells - showed that the use of $a$ with ditransitive verbs was significantly more accurate than with bivalent intransitive and transitive verbs, $\chi^{2}(1, N=51)=16.3 ; p<.001$ and $\chi^{2}(1, N=$ 76) $=33.6 ; p<.001$ respectively, with no significant difference between the latter two, $\chi^{2}$ $(1, N=45)=.01, p=.90$. 
Table 9

Accuracy of Grammatical Uses of A According to Syntactic Context

\begin{tabular}{lllllll}
\hline Level & Ditransitive Verb & \multicolumn{2}{l}{$\begin{array}{l}\text { Bivalent Intransitive } \\
\text { Verb }\end{array}$} & \multicolumn{2}{l}{$\begin{array}{l}\text { Transitive Verb with } \\
\text { Animate Direct Object }\end{array}$} \\
\cline { 2 - 7 } & Total & \% Correct & Total & \% Correct & Total & \% Correct \\
\hline Level 1 & 15 & 80 & 5 & 0 & 17 & 0 \\
Level 2 & 16 & 63 & 4 & 25 & 13 & 23 \\
Level 3 & 10 & 100 & 1 & 0 & 5 & 20 \\
All Levels & 41 & 78 & 10 & 10 & 35 & 11 \\
\hline
\end{tabular}

\section{Discussion}

The findings offer partial support for the hypothesis put forth by cognitive linguists that learners are sensitive to conceptual basicness and the semantic relationships among the different meanings of a preposition. As predicted, the more conceptually basic spatial and temporal uses showed greater accuracy than lexical and grammatical ones, and lexical uses, being more semantically transparent, were slightly more accurate than grammatical ones. However, contrary to the hypothesis, natural cognitive mechanisms did not appear to be the driving force behind development, that is, learners did not appear to be simply recreating the network of relationships among the meanings based on conceptual basicness and the transparency of the semantic extension. If that were the case, spatial uses should have preceded all others, including temporal ones. Rather, a close examination of the uses revealed that several other, non-conceptual factors might be at play, namely collocational patterns and cross-linguistic transfer, as well as psycholinguistic factors, such as frequency and saliency of the forms (Bybee, 2008; Ellis \& Cadierno, 2009). The influence of some of these factors has already been noted in previous studies, such as Lowie and Verspoor (2004), where prepositions with high frequency and high L1 similarity were acquired before those with only one of the two characteristics, and prepositions with low frequency and low L1 similarity were acquired last. While future studies are needed in order to clarify the extent to which each specific factor influences acquisition, Lowie and Verspoor's findings, together with those of the present study, indicate that such factors cannot be ignored when examining the development of prepositional meanings in L2.

In addition, as the participants learned a significant portion of their Spanish from the classroom, the role of instruction should also be considered. This study was unable to collect data on what the participants were learning at the time of data collection because they came from a variety of different classes, but future studies may wish to include such data. Certainly, some of the collocational patterns noted in this study, such as ir a [to go to] and $a$ las $X$ [at X o'clock], are generally taught as fixed expressions, which would encourage students to treat them as a single unit.

Other limitations include a small sample size and the fact that the study was not a true longitudinal one that traces development in the same group of learners, so there might have been unidentified confounding variables that could have affected the comparability of the groups. Moreover, the Level 1 participants were not at the initial stages of language acquisition but rather were already in the second semester of study, so it is possible that conceptual factors may play a larger role at the very early stages of acquisition when 
learners have not yet had enough exposure to the language to be sensitive to collocational patterns and frequency effects. Indeed, the study did not consider whether learners were at least aware of the conceptual relationships among the meanings, as this does not rule out their concurrent development. A task probing learners' receptive knowledge may help shed light on whether certain meanings of $a$ are easier to interpret than others. In addition, the story-telling task was not sufficiently controlled to elicit each of the meanings of $a$ at a comparable rate, and the range of uses was constrained by the pictures in the task. While such an instrument allowed for natural, spontaneous speech, it would be useful to include a more closed task where the different uses of $a$ could be better balanced. Future studies may also wish to examine different prepositions, especially ones that convey a stronger spatial meaning and are more semantically transparent than $a$, such as bajo [underneath], por [through], or hacia [towards], as it is difficult to examine conceptual processes when many of the uses of $a$ are highly lexicalized or grammaticalized and function essentially as collocates.

Despite these limitations, the results provide some insight on the acquisition of the meanings of the Spanish preposition $a$ by adult L2 learners. While much more data are needed using multiple tasks and targeting other prepositions, the findings from this study do concur with previous ones in suggesting that the development of prepositional meanings is far from systematic and is instead driven by multiple, concurrent processes. Although learners would perhaps have a much easier time with prepositions if they followed the model put forth by cognitive linguists, in practice learners may proceed in a much more chaotic fashion, relying on several different mechanisms simultaneously as they grapple with the many varied meanings associated with a single prepositional form.

\section{Conclusion}

Understanding the development of prepositional meanings in L2 learners is essential for determining why these words remain persistently difficult. While cognitive linguists should be commended for attempting to find some systematicity in the wide range of meanings that are associated with a single prepositional form, the results from this study and others suggest that L2 acquisition, at least, proceeds in more of a piecemeal manner. Learners seem to draw on a variety of processes to help them figure out which preposition to use in a particular context, ranging from natural cognitive mechanisms like metaphorical extensions, to non-conceptual ones such as cross-linguistic transfer, collocational patterns, as well as frequency and saliency in the input. Given the complexity of prepositional semantics, it is difficult to blame them for doing so.

Correspondence should be addressed to Yvonne Lam.

Email: yvonne.lam@ualberta.ca

\section{Notes}

${ }^{1}$ The term second language (L2) is used in a general sense to refer to any additional language, whether it be the second or the third or the fourth language learned. In this study, Spanish was not necessarily the second (chronological) language learned, as many participants knew multiple languages. 
${ }^{2}$ The different dialects of the native Spanish speakers may have influenced the frequency with which $a$ was used, as some expressions vary in their choice of preposition (e.g., sentarse a/en la mesa [to sit down at the table]).

\section{References}

Alexopoulou, A. (2006). Análisis de la evolución interlingüística y jerarquía de las dificultades en la interlengua escrita de aprendientes de español de origen griego. Revista Española de Lingüística Aplicada, 19, 9-28.

Azevedo, M. (1980). The interlanguage of advanced learners: An error analysis of graduate students' Spanish. International Review of Applied Linguistics in Language Teaching (IRAL), 18(3), 217-227.

Boers, F., \& Demecheleer, M. (1998). A cognitive semantic approach to teaching prepositions. ELT Journal, 52, 197-204.

Bybee, J. (2008). Usage-based grammar and second language acquisition. In P. Robinson \& N. C. Ellis (Eds.), Handbook of cognitive linguistics and second language acquisition (pp. 216-236). New York, NY: Routledge.

Cho, K. (2010). Fostering the acquisition of English prepositions by Japanese learners with networks and prototypes. In S. De Knop, F. Boers, \& A. De Rycker (Eds.), Fostering language teaching efficiency through cognitive linguistics (pp. 259-275). Berlin, Germany: Mouton de Gruyter.

Davies, M. (2002). Corpus del Español: 100 million words, 1200s-1900s. Retrieved from http://www.corpusdelespanol.org

Durrant, P., \& Schmitt, N. (2010). Adult learners' retention of collocations from exposure. Second Language Research, 7, 163-188.

Ellis, N. C., \& Cadierno, T. (2009). Constructing a second language: Introduction to the special section. Annual Review of Cognitive Linguistics, 7, 111-139.

Falk, Y., \& Bardel, C. (2010). The study of the role of the background languages in third language acquisition: The state of the art. International Review of Applied Linguistics in Language Teaching (IRAL), 48(2-3), 185-219.

González-Alvarez, E., \& Doval-Suárez, S. M. (2008). Testing the cognitive categorizations of at in native and non-native English speakers: Evidence from a corpus study. The Linguistics Journal, 3(1), 100-135.

Guntermann, G. (1992). An analysis of interlanguage development over time: Part 1, por and para. Hispania, 75(1), 177-187.

Hallan, N. (2001). Paths to prepositions? A corpus-based study of the acquisition of a lexico-grammatical category. In J. Bybee \& P. Hopper (Eds.), Frequency and emergence of linguistic structure (pp. 91-120). Amsterdam, Netherlands: John Benjamins.

Haspelmath, M. (1997). From space to time: Temporal adverbials in the world's languages. Munich, Germany: Lincom Europa.

Henning, G. (1978). A developmental analysis of errors of adult Iranian students of English as a foreign language. Language Learning, 28(2), 387-397.

Huerta, B. L. (2009). The semantics of the Spanish prepositions en, a, and de: A cognitive approach (Unpublished doctoral dissertation). University of Buffalo, State University of New York, Buffalo, NY. 
Ijaz, I. H. (1986). Linguistic and cognitive determinants of lexical acquisition in a second language. Language Learning, 36(4), 401-451.

Jarvis, S. (2000). Methodological rigor in the study of transfer: Identifying L1 influence in the interlanguage lexicon. Language Learning, 50(2), 245-309.

Jarvis, S., \& Odlin, T. (2000). Morphological type, spatial reference, and language transfer. Studies in Second Language Acquisition, 22, 535-556.

Jiménez Catalán, R. M. (1996). Frequency and variability in errors in the use of English prepositions. Miscelánea: A Journal of English and American Studies, 17, 171-187.

Lafford, B., \& Ryan, J. (1995). The acquisition of lexical meaning in a study abroad context: The Spanish prepositions por and para. Hispania, 78(3), 528-547.

Lam, Y. (2009). Applying cognitive linguistics to teaching the Spanish prepositions por and para. Language Awareness, 18(1), 2-18.

Lam, Y. (2010). Yes/no tests for foreign language placement at the post-secondary level. Canadian Journal of Applied Linguistics, 13(2), 54-72.

Lowie, W., \& Verspoor, M. (2004). Input versus transfer?-The role of frequency and similarity in the acquisition of L2 prepositions. In M. Achard \& S. Niemeier (Eds.), Cognitive linguistics, second language acquisition, and foreign language teaching (pp. 77-94). Berlin, Germany: Mouton de Gruyter.

Matula, S. (2007). Incorporating a cognitive linguistic presentation of the prepositions on, in, and at in ESL instruction: A quasi-experimental study (Unpublished doctoral dissertation). Georgetown University, Washington, D.C.

Morimoto, S., \& Loewen, S. (2007). A comparison of the effects of image-schema-based instruction and translation-based instruction on the acquisition of L2 polysemous words. Language Teaching Research, 11(3), 347-372.

Navarro i Ferrando, I., \& Tricker, D. (2000/2001). A comparison of the use of at, in, and on by EFL students and native speakers. Revista Española de Lingüística Aplicada, 14, 295-324.

Pinto, D., \& Rex, S. (2006). The acquisition of the Spanish prepositions por and para in a classroom setting. Hispania, 89(3), 611-622.

Rice, S. (1996). Prepositional prototypes. In M. Pütz \& R. Dirven (Eds.), The construal of space in language and thought (pp. 135-165). Berlin, Germany: Mouton de Gruyter.

Rice, S. (1999). Patterns of acquisition in the emerging mental lexicon: The case of to and for in English. Brain and Language, 68, 268-276.

Rice, S. (2003). Growth of a lexical network: Nine English prepositions in acquisition. In H. Cuyckens, R. Dirven, \& J. Taylor (Eds.), Cognitive approaches to lexical semantics (pp. 243-280). Berlin, Germany: Mouton de Gruyter.

Sandra, D., \& Rice, S. (1995). Network analyses of prepositional meaning: Mirroring whose mind - the linguist's or the language user's? Cognitive Linguistics, 6(1), 89130.

Taylor, J. (1988). Contrasting prepositional categories: English and Italian. In B. RudzkaOstyn (Ed.), Topics in cognitive linguistics (pp. 299-326). Amsterdam, Netherlands: John Benjamins.

Tyler, A. (2012). Cognitive linguistics and second language learning: Theoretical basics and experimental evidence. New York, NY: Routledge.

Tyler, A., \& Evans, V. (2003). The semantics of English prepositions. Cambridge, United Kingdom: Cambridge University Press. 
Tyler, A., Mueller, C., \& Ho, V. (2011). Applying cognitive linguistics to learning the semantics of English to, for and at: An experimental investigation. Vigo International Journal of Applied Linguistics, 8(1), 181-205. 


\section{Appendix A: Oral Story-Telling Task \#1}

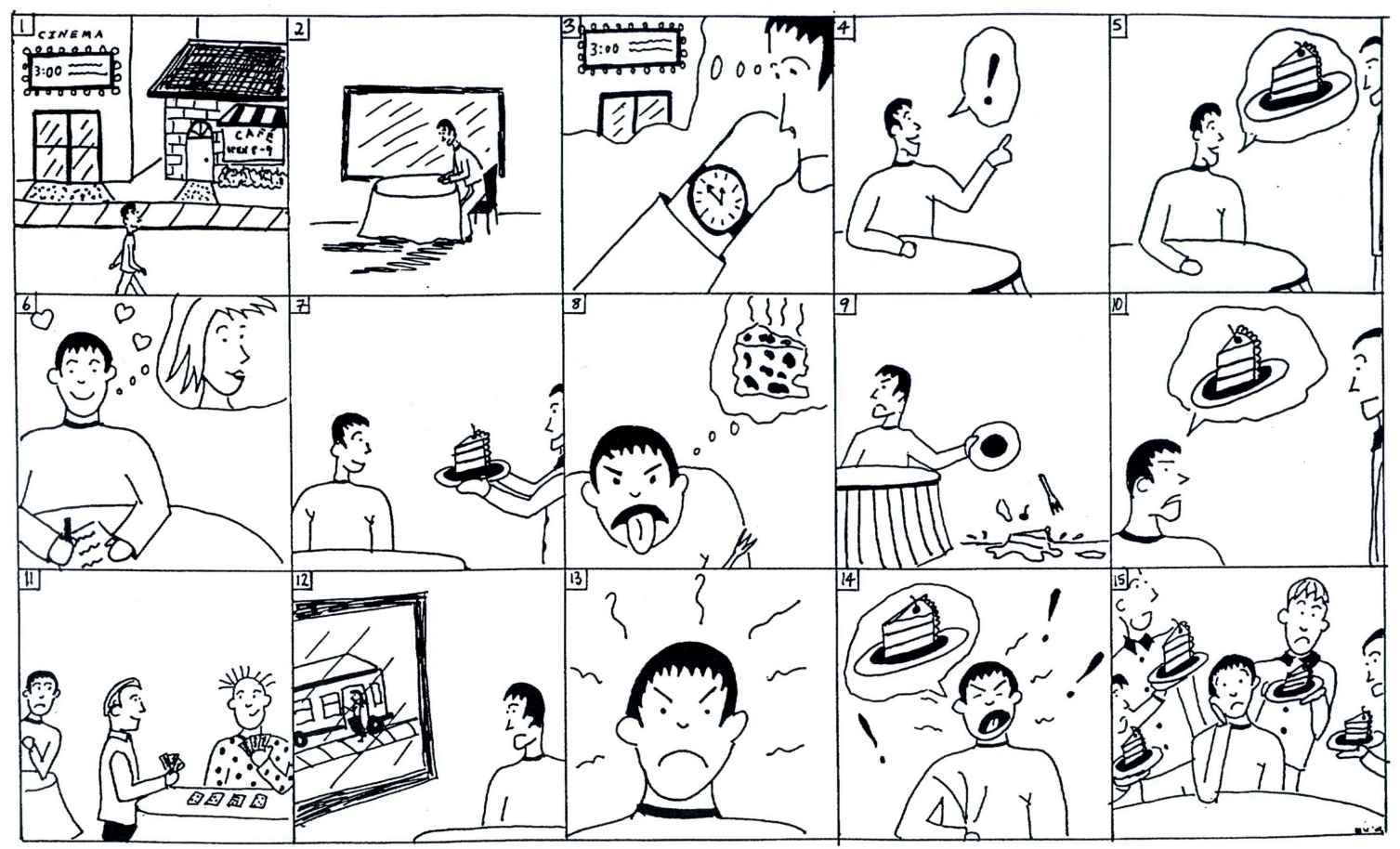

The Canadian Journal of Applied Linguistics: 21, 1 (2018): 1-22 


\section{Appendix B: Oral Story-Telling Task \#2}

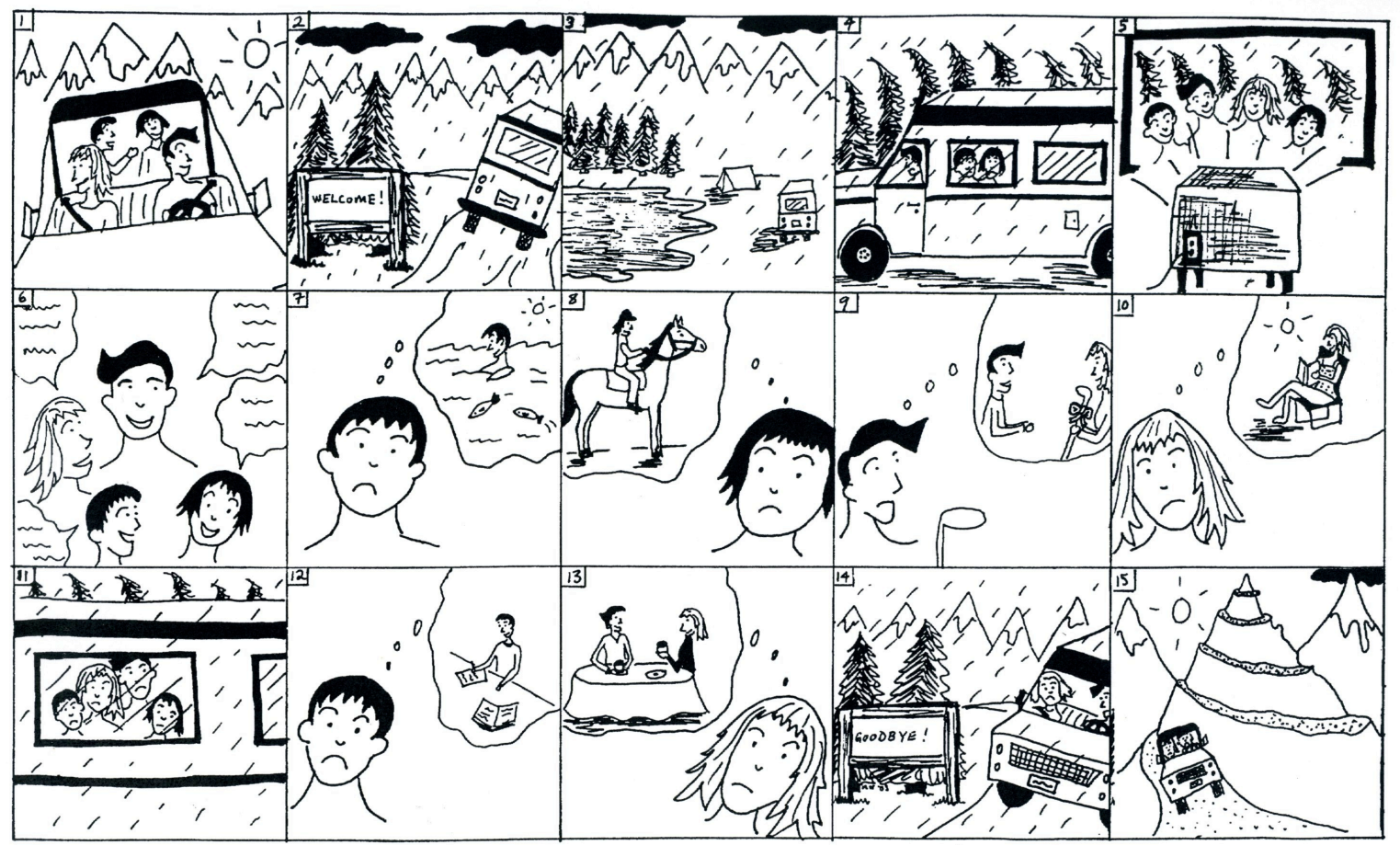

